\title{
Corporate Governance and the Environmental Politics of Shipping
}

\author{
Justin Alger | ORCID: 0000-0001-6737-2835 \\ University of British Columbia, Vancouver, British Columbia, Canada \\ justin.alger@ubc.ca \\ Jane Lister | ORCID: 0000-0003-2465-9320 \\ University of British Columbia, Vancouver, British Columbia, Canada \\ jane.lister@ubc.ca \\ Peter Dauvergne | ORCID: 0000-0003-2887-8168 \\ University of British Columbia, Vancouver, British Columbia, Canada \\ peter.dauvergne@ubc.ca
}

\begin{abstract}
A handful of companies dominate the world's shipping industry. These firms have gained political leverage over the global governance of container shipping in particular. Intriguingly, in recent years the Danish conglomerate Maersk - the world's biggest container and shipping vessel company since the mid-199os - has been using its influence to push for higher environmental standards for the industry as a whole. To some extent these initiatives are helping to promote environmental efficiencies, cleaner fuels, and greener technology. But they are also raising costs for small and midsized companies with extremely low profit margins, further enhancing the competitiveness of the biggest shipping conglomerates in an increasingly oligopolistic market. While voluntary self-governance by companies such as Maersk is incrementally improving the environmental management of global shipping, it is also further concentrating governance power within a few transnational corporations, potentially taking more ambitious regulation off the agenda.
\end{abstract}

\section{Keywords}

global shipping - corporate social responsibility - ocean governance - business power - environmental politics - maritime regulation

(C) JUSTIN ALgER, JANE LiSTER AND PETER DAUVERgNe, 2021 | DOI:10.1163/19426720-02701001 This is an open access article distributed under the terms of the CGBY-NC-ND 4.0 license. 


\section{Introduction}

In 1976, the political economist Susan Strange published a seminal article on the politics of global shipping in the journal International Affairs. The dispersed and international nature of shipping, Strange argued, made it particularly difficult for states or international agencies to exert any real control over the industry. In her view, the shipping industry was becoming less efficient, less equal, and more unstable as a result. ${ }^{1}$ Unknown to Strange, the industry was on the cusp of a dramatic expansion as globalization took off in the 198 os and as international trade skyrocketed after the 199os. This expansion has exacerbated the political, socioeconomic, and environmental challenges of an industry that forms the backbone of the global economy, today accounting for over 80 percent of international trade (by volume). Despite this rapid growth and the industry's exemption (along with aviation) from multilateral climate agreements, including the 2015 Paris Agreement, little analysis has been done to understand the environmental governance of global shipping.

Today, robust environmental governance of the global shipping industry remains elusive. There are mandatory international regulations in place such as the International Maritime Organization's (IMO's) energy efficiency measures, sulfur emissions controls, regulations on nitrogen oxides, rules on ballast water and sediments, and safety requirements to avoid oil spills. To some extent, these have improved environmental management, as this article documents. Many of the governance efforts to green the global shipping industry, however, have taken the form of international voluntary treaties and guidelines, national governments adopting unilateral targets, ports adopting rules and incentives that are often inconsistent with one another, and industry increasingly selfregulating under the rubric of corporate social responsibility (CSR). Many of these initiatives, despite shortcomings, are positive developments toward better environmental practice in the shipping industry. But they come at the cost of reinforced and increasing industry authority over global shipping governance. This continued ceding of state control to corporate governance reflects the broader trend toward private authority that scholars have noted across a range of sectors, as transnational corporations (TNCs) and their subsidiaries strive for economic power and business sustainability. ${ }^{2}$ Governance scholars of environmental politics, however, have largely neglected the shipping indus-

1 Strange 1976.

2 Clapp 2018; Mikler 2018. 
try, despite its unique position within the global economy as the key vehicle for international trade.

Corporate environmental governance of global shipping is worthy of scholarly attention because of the ability of major shipping companies to exert power and authority over their own regulation. Shipping company dominance has, we argue, afforded them exceptional political leverage to shape environmental governance to enhance their market position. Revealingly, the world's most powerful shipping company, Maersk, is not shying away from stronger environmental standards; it is pursuing higher standards as part of a strategy to consolidate and capture markets. The growing influence of major shipping companies creates a paradox for environmentalists. On the one hand, the environmental performance of the industry is improving as companies such as Maersk improve their operational efficiency, adopt and lobby for stronger emissions standards, and develop cleaner technologies. On the other hand, the future governance of the industry will depend increasingly on the support of the biggest and most powerful companies, which risks removing more ambitious environmental regulation from the agenda.

We start our analysis by examining the evolution of global shipping since 1976, demonstrating how rapid growth and consolidation have affected the environmental performance of the industry, for good and ill. Next, we argue that the capacity for private authority in the industry is uniquely high given the industry's geopolitical importance and its ubiquity in the global economy. We then analyze the strengths and weaknesses of state-based governance of the shipping industry. After that, we analyze voluntary environmental governance within the global shipping industry, focusing on Maersk to show how some powerful shipping companies are employing environmental governance as a tool to outcompete their rivals and shape the regulatory agenda. We conclude by reflecting on what our analysis suggests for the future environmental performance of the global shipping industry. Our analysis throughout focuses on container shipping, where trends toward consolidation and self-governance are most prominent, and where major ship operators face pressure from consumerfacing brand retailers looking to enhance the sustainability of their supply chains. $^{3}$

3 Dauvergne and Lister 2013. 
In 1976, Strange wrote about a world economy that was increasingly interconnected and consciously interdependent. She argued that the tendency of powerful states toward bilateral agreements was a way for them to consolidate their hold on the shipping industry. For Strange, these agreements would reduce the efficiency of the global shipping industry by undermining it as a competitive market. The main casualty of this tendency was equity—developing countries would find themselves both economically and politically unable to exert any influence over a consortium of wealthy shipping nations. The prospects for equity in global shipping, Strange predicted, were bleak.

Strange was, of course, right. But while she identified protectionism in the form of bilateral collusion as the main culprit, it is increasingly liberated global markets, including for shipping, that have allowed the largest shipping companies to grow in influence. Protectionism in the form of cabotage, subsidies, and tax concessions have certainly endured, distorting the market and making it difficult for newcomers to compete. But Strange could not have predicted the extent to which economic globalization would take off in the 1980 s, nor the subsequent explosion in international trade. The volume of maritime trade more than quadrupled from 1970 to 2019 , from 2.6 to 11.1 billion tons. ${ }^{4}$ Enduring protectionism has not reduced equity in global shipping as much as the sudden, ongoing need for larger ships capable of traveling longer distances.

Such a rapid growth in trade has, in other words, put a premium on scale. The most obvious solution to larger volume is to increase the number of ships on the water, but it is not the most significant. From 1970 to 2017, the number of vessels in operation increased by 78 percent- from 52,444 to $93,161-$ compared to a 224 percent increase in trade volume. ${ }^{5}$ But from 1975 to 2017 , the industry's global capacity has expanded dramatically from 546 million deadweight tonnage to nearly 2.0 billion deadweight tonnage, a nearly fourfold increase that is in line with the growth in global trade. ${ }^{6}$ The shipping industry has not met increased demand just by expanding its fleet but also by building larger ships which are, of course, more expensive. Globally, the capacity of the average container ship more than doubled from 1996 to 2019, with container ships built in the last four years on average four times larger than one

4 UN Conference on Trade and Development 2020, 4.

5 Eyring et al. 2005, 10; UN Conference on Trade and Development 2020, 37.

6 UN Conference on Trade and Development 1976, 8; UN Conference on Trade and Development 2020, 41. 
built twenty years ago. ${ }^{7}$ By expanding the size of their fleets and the carrying capacity of their ships, the industry has been able to keep pace with rapid trade growth. These efforts have simultaneously allowed major industry players to achieve economies of scale that allow them to outcompete smaller companies.

Average ship size alone does not capture the dramatic shift in scale over this forty-year span. The largest container ship in use in 1968 was roughly 1,500 TEU (twenty-foot equivalent equal to a standard-sized container), whereas in 2020 it was over 21,00O TEU—a more than fourteenfold increase. ${ }^{8}$ Megaships are increasingly dominating global shipping, particularly since the collapse of shipping rates following the 2007-2008 financial crisis, and the implications of this dominance for the structure of the industry are severe. With fully loaded vessels, it leads to economies of scale in the form of reduced salary and fuel costs for major shippers, allowing them to offer lower prices than smaller competitors. It also leads to structural overcapacity with the industry able to ship more goods than demanded, and a consequential drop in shipping rates. The capital-intensive strategy of achieving economies of scale through megaships is not an option for smaller carriers.

The cumulative effect of this premium on scale has been to push smaller carriers out of business, forcing many into mergers with the largest companies. By 2019, the top five container shipping companies accounted for 67 percent of global TEU capacity -6 percent more than a year earlier. This rise was in part due to the collapse of Hanjin, and Maersk's acquisition of Hamburg Süd (along with new megaships) that further increased Maersk's TEU industry share. At the same time, COSCO Shipping's 2018 takeover of the Hong Kong-based Orient Overseas Container Lines helped boost the Chinese company's market share. But the growth in the TEU capacity of the top five companies also reflects a longstanding trend of consolidation. Figure 1 represents the realization of Strange's worst fear for the industry. Smaller carriers have never been more disadvantaged in global shipping than they are now in this era of megaships and consolidation. The majority of this concentration is occurring in container shipping. Smaller carriers have fared better in bulk and tanker shipping, particularly along shorter shipping routes.

7 UN Conference on Trade and Development 2020, 37.

8 World Shipping Council 2021. 


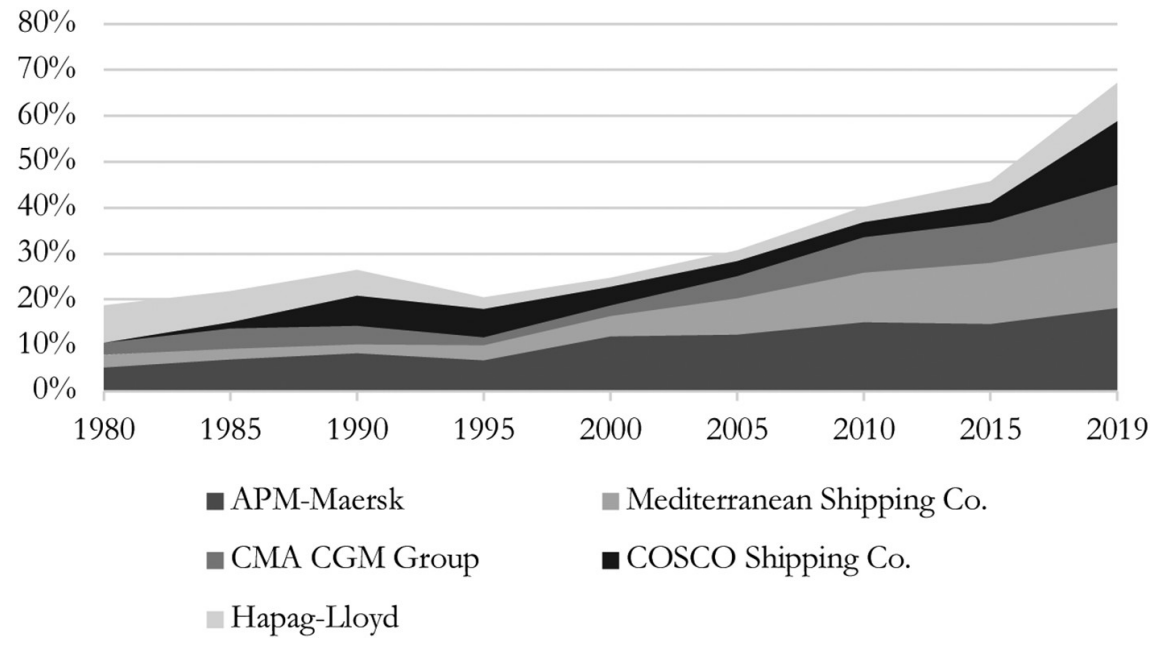

FIGURE 1 Industry share of top five (in 2019)

UN CONFERENCE ON TRADE AND DEVELOPMENT 2019

This consolidation is all occurring in tandem with the internationalization of supply chains since the 1970s-a secondary driver of growing shipping demand. According to the International Monetary Fund (IMF), the foreign content share of gross global exports nearly doubled from 1970 to $2013 .{ }^{9}$ During the same time, the global aggregate value-added exports (VAX) ratio fell from 0.87 to $0.77 .^{10}$ The VAX ratio is a key indicator of the interdependence of supply chains. It measures the ratio of exported goods that are refined or processed domestically to add value to them relative to intermediate goods that are merely in transit. The drop in the ratio indicates that companies are increasingly moving goods through more countries before they reach their final destination. This movement is primarily a consequence of transnational corporations gaining access to cheaper labor and resources abroad. The efficiency of these savings more than outweighs the inefficiency of transporting intermediate goods. For the shipping industry, this means that the same goods are shipped more often, raising the demand for goods transport. From 1988 to 2015, total exports of intermediate goods increased twentyfold in value, from $\$ 190$ billion to $\$ 3.8$ trillion. ${ }^{11}$ This shift is not without consequence for the industry. While global supply chains facilitate global economic development, they also increase global inequality as corporations look to capture profit by exerting

\footnotetext{
$9 \quad$ International Monetary Fund 2013.

10 Johnson and Noguera 2012, 58.

11 World Integrated Trade Solution 2018.
} 
their market, social, and political power. ${ }^{12}$ The internationalization of supply chains is a key driver of industry consolidation in recent years, as developing countries and small and midsized shipping companies find themselves unable to keep up.

These trends-rapid growth, economies of scale, consolidation, and internationalization - have in conjunction allowed for a high degree of industry influence over its environmental governance. Marine shipping already boasts the lowest carbon emissions per ton-kilometer, beating out air, rail, and truck transport. Major industry players-alongside the International Maritime Organization-have focused their efforts on energy efficiency, which benefits both bottom lines and the environment. IMO-led initiatives have focused on industry-friendly, nonbinding governance mechanisms, including technical requirement guidelines and creating opt-in low-emission regions, notably in the Baltic Sea, North Sea, US Caribbean, and coastal Canada and the United States. ${ }^{13}$ Major shipping companies have successfully designed more fuelefficient ships in recent years, primarily through achieving economies of scale. Modern megaships ( 19,000 TEU) incur fuel savings of between 40 and 46 percent per ton-kilometer relative to a standard 8,500 TEU model. Megaship designs are becoming so optimized, in fact, that a new 19,0oo TEU ship actually consumes less aggregate fuel than early $14,000-16$, ooo TEU ships..$^{14}$ Consolidation and economies of scale have already led to better fuel efficiency, reducing the climate impact per ton-kilometer of the industry. With dozens more megaships on order for large shipping companies, the industry's fuel efficiency is likely to improve further in coming years.

Of course, the problem is that any gains in efficiency are more than offset by the industry's rapid growth. As projected, shipping emissions roughly doubled from 1970 to $2018 .{ }^{15}$ The IMO also projects that shipping carbon emissions will rise between $5^{\circ}$ and 250 percent by 2050 under a business-as-usual scenario. ${ }^{16}$ Fuel efficiency matters for minimizing the environmental impact of shipping, but any gains risk being overshadowed by rising aggregate emissions. There is a similar challenge with emissions reduction efforts in ports. Despite regulatory efforts in many cities to reduce air pollution from ports, the IMO projects that port emissions are still likely to quadruple by $2050 .{ }^{17}$ The 100 most polluted

\footnotetext{
12 Stiglitz 2019.

13 Wan et al. 2016.

14 International Transport Forum 2015, 23.

15 Endresen et al. 2007; International Maritime Organization 2015.

16 International Maritime Organization 2015, 20.

17 International Transport Forum 2014, 17-24.
} 
ports alone affect approximately 230 million people. ${ }^{18}$ Building larger, more fuel-efficient ships is not enough to address these threats to the environment and human health.

Focusing strictly on carbon emissions also risks neglecting the myriad of other environmental impacts of the shipping industry. As ships burn the lowest-grade heavy fuel oil (bunker fuel), the emissions include not just carbon but also sulfur dioxide, hydrocarbons, and various forms of nitrogen oxide, all of which have substantial environmental and human health effects. Low-grade marine fuel contains, for example, 3,500 times more sulfur than road diesel.19 According to one study, 3 o percent of atmospheric sulfur aerosol around major shipping routes is directly attributable to shipping, contributing to the occurrence of acid rain and more intense storms. ${ }^{20}$ Other threats include oil spills, invasive species, disposal of hazardous material, and noise, among others. These environmental threats from global shipping have all grown since the 1970 despite progress in reducing emission rates.

These trends point to a global shipping industry that looks much different today than it did in the 1970s. Transnational regulation and governance are an increasingly pervasive feature of both world affairs and scholarly analysis. An analysis of global shipping in the twenty-first century needs to account for the growing influence of corporations in global governance. Corporations, in many ways, now exert greater influence than states over global issues of stability, equity, and efficiency. This is especially true within the shipping industry.

The shipping industry is the oldest transnational business and the transmission belt of the global economy. Historically, shipping and geopolitical power have gone hand in hand. In the past, it has been in the interest of states to limit regulations on the high seas to facilitate open competition and economies of scale in trade. The prevailing norm for high seas governance has been freedom of the seas-a norm that shipping companies have worked to reinforce in their efforts to avoid state regulation and consolidate their position. The industry's privileged position in the global economy has made it especially effective in influencing its own governance.

\footnotetext{
18 International Transport Forum 2014, 23.

19 Wan et al. 2016.

2 Capaldo et al. 1999, 743.
} 
The freedom of the seas norm is central to why the shipping industry continues to be so difficult for states to regulate. ${ }^{21}$ This difficulty is partly the result of state design. Historically, states have advocated for minimal regulations at sea in pursuit of their strategic and economic interests. The legal justification for freedom of the seas dates back to 16o9, when Dutch jurist Hugo Grotius made the case that shipping routes and ocean resources were inexhaustible resources and therefore should be available to all states equally — an important geostrategic priority for the then Dutch Republic. ${ }^{22}$ Grotius naturally could not predict the scale of extractive activity centuries later, but his legal basis for freedom of access to shipping routes largely endures today. The norm featured prominently throughout the ten-year negotiations for the UN Convention on the Law of the Sea (UNCLOS) adopted in 1982. As the world's preeminent maritime powers throughout the nineteenth and twentieth centuries, the United Kingdom and United States viewed freedom of the seas as essential to the health of their economies. They used their collective power to enshrine it in international law. The evolution of the shipping regime since-around issues such as jurisdictional rights, damage control, and technical barriers - similarly reflects the prerogative of states to ensure free movement of ships and commerce.

The historical state-based governance of shipping has, in short, worked toward enhancing industry autonomy in the name of geopolitics and commerce. States actively promoting industry autonomy gave major industry players a lot of leeway over how to organize, through their own banks and insurance companies, and most notably through loosely regulated industry "conferences" (essentially cartels)..$^{23}$ These conferences coordinated on maintaining control over certain shipping routes, often deliberately deploying ships on the same schedules as non-members to push them out of the market. ${ }^{24}$ Pushing smaller competitors out of the market allowed these conferences to fix prices at a higher rate, among other predatory business practices. The conference system would not endure, however. The emergence of containerization in the latter half of the twentieth century reduced shipping costs, making the market more competitive for smaller companies..$^{25} \mathrm{New}$ antitrust laws targeting conferences in Europe and the United States at the beginning of the twenty-first century

\footnotetext{
21 To maritime historians, "freedom of the seas" often refers to the legal regime for the high seas that predated the UN Convention on the Law of the Sea. We adopt its broader meaning of unrestricted and open access to ocean spaces.

22 Nyman 2017.

23 Cutler 1999; Franck and Bunel 1991.

24 Munari 2012.

$25 \quad$ Franck and Bunel 1991.
} 


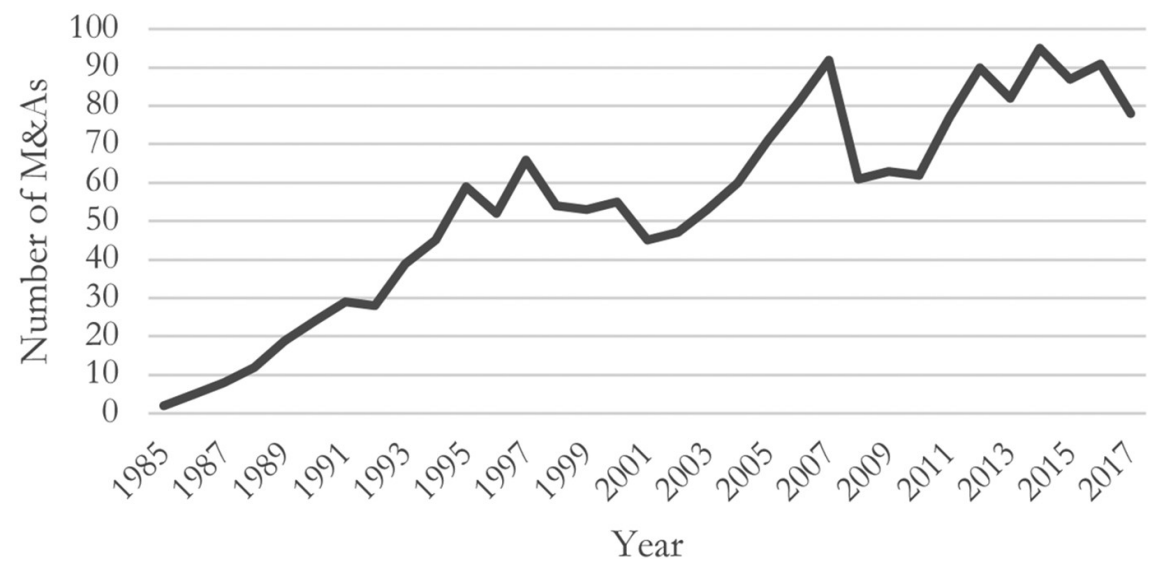

FIGURE 2 Industry consolidation: mergers and acquisitions

ALEXANDROU, GOUNOPOULOS, AND HARDY 2O14; THOMSON REUTERS [N.D.]

followed, further undermining their viability. These regulations were intended to break up what was increasingly an unfair, oligopolistic market, but they had the unanticipated effect of providing the impetus for the further centralization of authority in the industry.

This centralization of power has taken two forms: an increase in mergers and acquisitions, and the formation of shipping alliances. The high fixedvariable cost ratio of the shipping industry makes consolidation an imperative for major shipping countries. ${ }^{26}$ With the benefits of coordinating routes and prices through conferences increasingly restricted by governments, major industry players have resorted to strategic mergers and acquisitions to achieve greater economies of scale. Figure 2 depicts the sharp rise in these mergers and acquisitions in the 199os that has continued steadily since. Some of these mergers reflect a dramatic shift in industry composition. For example, the merger of COSCO and China Shipping in 2016-China's two largest state-owned shipping conglomerates-made COSCO Shipping the world's fourth-largest shipping company at the time (it has since risen to third).

Strategic alliances also emerged to replace conferences, and these now dominate the shipping landscape. The market share of the major alliances leaped from 30 percent in 2011 to 80 percent in 2018, depicted in Figure 3. Just three alliances-Ocean Alliance, The Alliance, and $2 \mathrm{M}$ Alliance-now account for 80 percent of global capacity. Formed in 2017 following a reshuffling, these three alliances allow major carriers to coordinate to enhance their global ser-

$26 \quad$ Franck and Bunel 1991. 


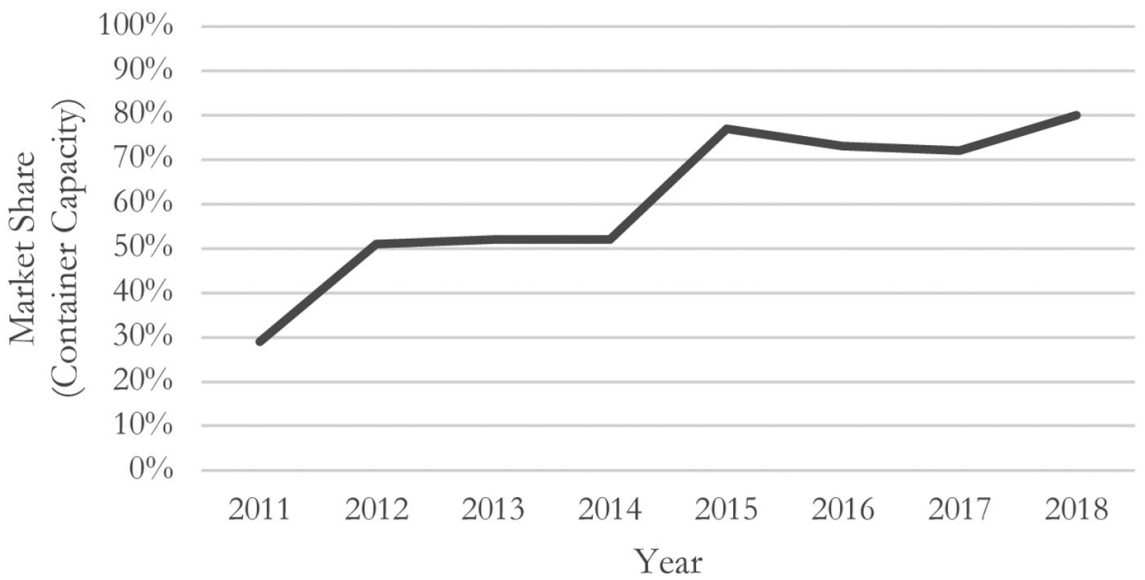

FIGURE 3 Industry consolidation: market share of major alliances

Measures market share of top four alliances until 2017, when major industry players reshuffled alliances to form three instead INTERNATIONAL TRANSPORT FORUM 2018

vice coverage and optimize operational costs by sharing resources. The major distinction between these alliances and the conferences of old is that alliance partners do not share commercial information, including pricing. But in practice, these alliances allow a select few large shipping companies to dominate the industry even further. Minimal government antitrust efforts and lingering liner shipping block exemptions from competition policy have enabled the ongoing formation of an oligopoly in global shipping — driven by the advent of megaships and by the steady increase in industry consolidation through mergers, acquisitions, and alliances that began in the 1990s. ${ }^{27}$

The industry has, in short, been highly effective in avoiding regulation or in finding creative ways to limit its efficacy. There is perhaps no clearer instance of this than the "flags of convenience" model, by which ships can choose which country's flag to fly. This model allows ships to fly the flag of a country of its choice, including those with minimal safety and environmental regulatory requirements. Countries that ignore IMO resolutions have an outsized ability to undermine new standards. Rather than adhering to new rulesenvironmental or otherwise-ships often can simply switch flags and ignore them altogether. This system has endured because it benefits all parties: flag states get more traffic, non-flag states get cheaper shipping costs, and shipping

27 Sys 2009; International Transport Forum 2018. 
companies get increased profits. ${ }^{28}$ One possible solution is for governments to adopt an exclusion model that prohibits port access to ships that fly flags of convenience. ${ }^{29}$ But progress has been slow. In 2017, the five largest shipping fleets by flag of registration were Panama, Liberia, the Marshall Islands, Hong Kong, and Singapore. ${ }^{30}$ This model continues to allow ships to pick and choose which country's regulations to adhere to, vastly undermining the ability of the IMO and national governments to set standards. ${ }^{31}$

The freedom of the seas norm that states have long sought to reinforce has had perverse effects on global shipping governance. Mergers and acquisitions, conferences, alliances, and flags of convenience all contribute to an industry structure that has systematically reinforced the power of major corporations. For their part, states have struggled to identify the right balance between the geopolitical and commercial importance of freedom of the seas and the need to regulate the industry (environmental or otherwise). Even when states do introduce new rules, they tend to have unintended consequences. Antitrust efforts helped break up shipping conferences, but led to today's structure of powerful alliances. From price fixing to alliances to regulatory evasion, major corporations have significantly enhanced their market dominance and, by extension, their political power over global shipping - an outcome with perhaps unexpected consequences for the environmental governance of the industry.

\section{Environmental Governance of Global Shipping}

The consolidation of the industry since the 1970s and the freedom of the seas approach to shipping governance have allowed major companies to exert substantial influence over their environmental governance. Consolidation can benefit states looking to better regulate industry by, most notably, making it easier to design and target regulations in an industry with fewer larger firms. But consolidation also means a few firms have substantial market power that they can leverage to shape the content of state regulation, or oppose it outright. The industry has used that leverage in tangible ways to shape the environmental governance of shipping.

Historically, that influence has translated into efforts to avoid environmental regulation. The shipping industry was one of only two industries exempted

\footnotetext{
28 DeSombre 2008.

29 DeSombre 2006, 2008.

$30 \quad$ UN Conference on Trade and Development 2017.

31 Lister, Poulsen, and Ponte 2015.
} 
from emissions cuts in the 2015 Paris Agreement on climate change-a trend that continues its similar exemption from the 1997 Kyoto Protocol. Shipping is responsible for approximately 3 percent of global carbon emissions, which would put it in the top ten global emitters if considered a country, so its exemption is a major blow to the climate regime. Environmentalists lamented the shipping exception, decrying the "corporate capture" of the IMO and UN by shipping and air transport lobbyists. But the global shipping industry has been nigh untouchable for states looking to curb the sector's climate change impact.

This untouchable status is partly by design. In addition to an embedded freedom of the seas norm, the industry further benefits from the norm of liberal environmentalism, which emerged out of the negotiations and compromises leading up to the 1992 UN Conference on Environment and Development (UNCED), often referred to as the Rio Earth Summit. ${ }^{32}$ In Rio, states confirmed the need to better protect the global environment, but with the major caveat that efforts should not interfere with economic growth and development. Ever since, this compromise has defined the state-led governance of environmental issues from climate change to deforestation to biodiversity loss. The maritime industry agreed to support the Rio agenda only as long as it could set its own regulatory agenda. ${ }^{33}$ As the transmission belt of the global economy, it was simply too essential to all countries to risk disruption. Exemptions in Paris and Kyoto, and the so-called corporate capture of the IMO, therefore merely reflect the application of this norm to global shipping and its centrality in the global economy.

That is not to say that state-led governance of shipping has not been strong and successful at times. For example, states took action on oil spills by imposing stricter spill prevention standards on the industry. Oil spills can seriously damage corporate reputation, much more so than diffuse, long-term environmental impacts such as emissions. They have a lasting, visible impact, and generate public outcry. The industry has therefore been responsive to tougher IMO resolutions and technical guidelines for oil spill prevention. ${ }^{34}$ Despite the cost of implementing stricter safety standards in ship design, the industry sees the value in ceding authority on certain issues to external organizations such as the IMO. Adhering to best practices, as defined by outside governance bodies, has led to a sharp reduction in spills since the 1970s, as depicted in Figure 4. But it also provides the industry with a scapegoat in the event of a spill. Rather than a focus on internal malpractice, many oil spills become a lightning rod for

$32 \quad$ Bernstein 2001.

33 UN Conference on Trade and Development 2003.

34 Mitchell 1994. 


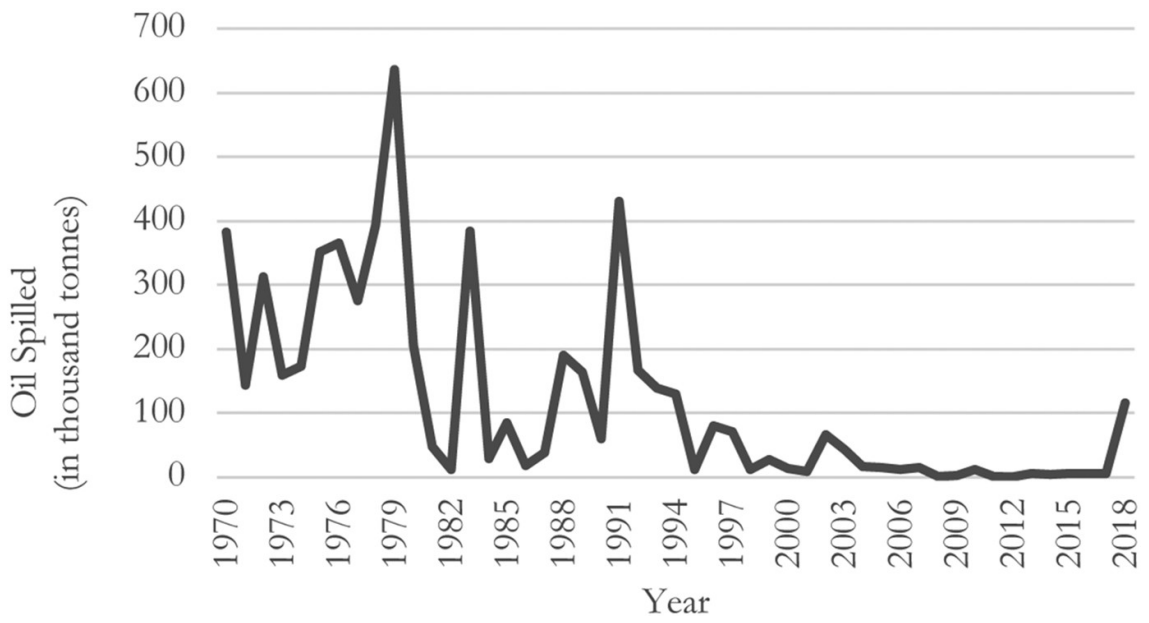

FIGURE 4 Quantity of oil spilled per year

INTERNATIONAL TANKER OWNERS POLLUTION FEDERATION 2018

reviewing the international standards set by the IMO. Oil spills can be reduced in number and their impact mitigated, but they are an inevitability of ship bunkering (refueling) and oil transport. By ceding authority on oil spills, the industry has effectively deflected the burden of responsibility to governments and international bodies on a high-profile, potentially market-damaging issue.

Similarly, in 2008 the IMO adopted a sulfur cap of o.5 percent of fuel composition to come into effect on 1 January 2020 - a sizable decrease from the previous 3.5 percent limit. This regulation applies to all new and existing ships, generally requiring that ships substitute cleaner, more expensive fuel, but also requiring retrofitting of tanks and engines in many older ships. Individual flag states are still responsible for sanctions in the event of noncompliance, but the IMO has adopted a particularly aggressive stance on sulfur emissions, raising its profile as an environmental priority and effectively ratcheting up pressure on industry. Given the pressure, major industry players are expected to comply, with a projected cost for the container shipping industry of between $\$_{5}$ billion and $\$ 3$ o billion, depending on market rates for fuel. ${ }^{35}$ Regulations such as those for oil spills and the sulfur cap demonstrate that state-led governance of shipping can be effective with industry buy-in, often gained through political pressure. States can and have put limitations on certain activities with real consequences for the industry. But new safety designs, ship retrofitting, and cleaner fuels are costly. Given the potential cost of new regulations, major ship- 
ping companies have not sat idly by, instead taking the initiative to better shape the environmental governance of their industry through self-regulation.

Following the lead of their big brand customers like Coca-Cola, IKEA, Walmart, and countless others, the major shipping companies are seeking to control their regulatory fate through self-governance and CSR initiatives. By voluntarily committing to sustainability, these companies can simultaneously reduce the impetus for government-led regulation, while setting the terms of debate for future regulation. ${ }^{36}$ When companies environmentally self-regulate, even with unambitious goals, they tend to dissuade voters, activists, and government officials alike from supporting more robust regulations. ${ }^{37}$ They also create benchmarks for the rest of the industry to follow and they influence the agenda for state-led governance. In doing so, the companies enhance their autonomy from government-imposed regulation, allowing them to shape the future of the industry and protect their profitability. Put simply, through CSR major shipping companies gain political authority to decide which environmental issues to address, and how to address them in a way that will not have an oversized effect on their bottom line. The cost of these self-imposed initiatives is a price well worth paying to avoid the potential losses associated with a rigorous stateled regulatory regime.

One such example was the approach that the International Chamber of Shipping (ICS) took to IMO-imposed greenhouse gas emissions reductions. Just as the IMO was advancing with a 2017-2023 road map for reducing greenhouse gases, the ICS submitted an alternative proposal to the IMO that voluntarily permitted the organization to impose reductions beginning in 2023 . The ICS proposal did not specify any reduction targets. The IMO accepted the industry proposal, feeling that industry buy-in was important for compliance. But the cost of this buy-in was high. The proposal marginalized and delayed action, with the IMO ultimately setting an intensity target for 2030 while pushing back the absolute emission reduction target to 2050 - letting industry off the hook in the short term. The ICS effectively co-opted the IMO reductions targets. Their watered-down proposal was representative of many CSR initiatives - weak, voluntary industry commitments that fail to adequately

$36 \quad$ Dauvergne and Lister 2013.

37 Malhotra, Monin, and Tomz 2019. 
address the environmental problem in question. ${ }^{38}$ In this case and others, the industry used its bargaining power to supplant a more ambitious, IMO-driven plan. To the IMO - an organization that struggles with compliance-having industry on board was more important than rigorous emissions targets. In this instance, small and large firms unified through the ICS to undermine the IMO plan but, increasingly, just a few firms are able to go it alone to similar result.

More recently, major industry players are moving toward greater environmental self-governance, as exemplified by green ship certification schemes. Spearheaded by industry leaders, these voluntary CSR programs, such as RightShip, Clean Cargo, Green Award, Green Ship of the Future, Environmental Ship Index, and the Clean Shipping Index, establish benchmark criteria to assess vessels on their environmental performance. They mainly measure carbon emissions and fuel efficiency. Ships that pass the mark receive a positive ranking and green seal of approval that qualifies the vessel for market incentives such as reduced port fees and better slot allocation at port. These ratings also bestow a market advantage to companies with certified vessels by allowing them to appeal to cargo customers seeking more environmentally responsible transport. More importantly, the voluntary standards are providing the industry with the opportunity to shape environmental rules. Container shipping companies representing approximately 85 percent of the world's ocean container shipping volume, for example, participate in the Clean Cargo Program, which includes a business Climate Call to Action agenda.

\section{Environmental Self-Governance at Maersk}

Beyond industry-led certification, there are a select few companies that are proactively pushing for better environmental regulation, most notably Maersk (or what is more formally known as A.P. Møller-Mærsk A/S). Maersk's sustainability initiatives and its advocacy for better environmental performance by the industry have earned it a positive reputation, even among industry critics. InfluenceMap's report on corporate capture of the IMO, for example, specifically lauds Maersk for its transparency and progressive voice in an otherwise scathing report. ${ }^{39}$ As Maersk CEO Søren Skou puts it, "Companies can no longer stay on the sidelines when it comes to global issues." ${ }^{\text {40 }}$ Maersk has been proactive on environmental governance, and its efforts are transforming

\footnotetext{
$38 \quad$ Dauvergne and Lister 2013; Wilks 2013.

39 InfluenceMap 2017.

40 A.P. Møller-Mærsk A/S 2018, 3.
} 
not only the company but the industry itself. Other companies and associations concentrated in Northern European countries are already starting to follow suit and support environmental action such as through the Trident Alliance lobby for strong sulfur fuel regulation and enforcement.

Beyond gaining political influence, there is a powerful business case for Maersk's support for stronger environmental governance. The business value, we argue, goes beyond the standard CSR "eco-business" from enhancing environmental efficiencies, reducing waste, and gaining more control of supply chains. ${ }^{41}$ Given the nature of the global shipping industry, higher environmental standards are giving Maersk a significant competitive advantage. New environmental regulations tend to raise the costs of shipping in an industry with already low profit margins, especially for smaller carriers that cannot take advantage of economies of scale. Companies such as Maersk that benefit from the cost savings of megaships and alliances are much better positioned to absorb these kinds of financial shocks than smaller companies. Maersk wields substantial power as the market leader in an increasingly centralized industry, allowing it to pressure governments and ports to make new environmental standards compulsory and ensure "level-playing-field" enforcement to guard their competitive margins. The inevitable outcome of rising operating costs is further industry consolidation through mergers and acquisitions, smaller companies put out of business, and rising barriers to entry for aspiring companies. By escalating environmental requirements and, therefore, risks and costs on its competitors, Maersk solidifies its industry dominance.

Maersk's position on sulfur emission limits in the Port of Hong Kong exemplifies how a powerful company exerts its influence to push for stronger environmental regulations to give it a competitive advantage. In 2012, the Port of Hong Kong cut port fees in half for ships that used fuel with no more than 0.5 percent sulfur content. Maersk, along with seventeen other companies, took advantage of the program. But in 2013 Maersk threatened to switch back to cheaper, dirtier fuel if the port did not make the cleaner fuel mandatory for all. Maersk claimed the cleaner fuel cost an additional $\$ 2$ million per year, only 40 percent of which was made up by cost savings from reduced port fees. This increased cost, Maersk argued, put it at a competitive disadvantage relative to its major competitors in East Asia. ${ }^{42}$ Maersk, however, was already using lowsulfur content fuel on its ships in part because it needed to abide by European standards. Its threat to switch to dirtier fuel was therefore somewhat hollow, as

41 Dauvergne and Lister 2013.

42 Wang, Park, and Khan 2013. 
was its calculation of the additional cost to Maersk. Maersk's incentive was certainly to level the playing field and it did so by pushing the Port of Hong Kong to adopt the same standards Maersk was already using internally. Bowing to Maersk, its largest customer, the Port of Hong Kong made the reduced-sulfur content fuel mandatory on all ships in 2015. Maersk is used here as an illustrative example, but Nordic shipping companies in particular are increasingly employing tactics similar to Maersk's pressuring of the Port of Hong Kong.

While the majority of shipping companies, often represented by the International Chamber of Shipping, remain silent on environmental issues, some of the largest shipping companies have been anything but. There are two key reasons why some of the major players like Maersk are becoming more environmentally conscious. ${ }^{43}$ The first is that they are more inclined to long-term planning. They see competitive advantage in being ahead of the curve on environmental performance, allowing them to attract environmentally conscious customers. As IKEA, Nike, Walmart, and others commit to sustainable supply chains, their public image increasingly depends on reducing the environmental cost of shipping. The CEO s of companies like Amazon, Cargill, and Walmart consistently rank in the top 100-and frequently the top 20-in lists of the most influential people in global shipping. Transnational retailers are increasingly looking to shipping emissions as one way of reducing their environmental footprints and enhancing their sustainability credentials. Large shipping companies are therefore using their strong market positions to capitalize on this growing demand for green shipping. Maersk, for example, has established "carbon pacts" with its major suppliers, notably Tetra Pak, BMW, and AkzoNobel, to meet the growing demand for greener ocean transport. Such pacts are also, however, a highly strategic means to lock customers into a long-term business relationship.

The second reason is that companies such as Maersk tend to be more technologically advanced than their competition. The better environmental performance of these companies is due in large part to this technological prowess. This prowess not only includes their ability to design and build more fuelefficient megaships, but also to conduct industry-leading research and development into the low- or zero-emissions vessels of the future. Many of these vessels will use cleaner fuels such as liquefied natural gas (LNG) and hydrogen, while others use advanced battery, fuel cell, wind, and solar technology. Whereas most shipping companies focus on operational measures such as improved maintenance and slow steaming for better fuel efficiency to address sustain- 
ability, the major industry sustainability leaders are pursuing fundamentally new ship designs. Being ahead of the curve with these advancements gives the big players an incentive to push for stricter environmental standards. Any new environmental regulations would have a greater impact on competitors lagging behind on these technologies. While the main target of these tactics may be major competitors (i.e., large Chinese shipping companies), the increased costs to smaller shipping companies are, at best, collateral damage. At worst, they represent systematic efforts by the world's largest shipping companies to force their smaller competitors out of the market.

The efforts of Maersk to use sustainability to enhance its market position is increasingly common in environmental governance. Corporations regularly look to co-opt environmental governance to set the terms for it. ${ }^{44}$ But as Strange noted in 1976, global shipping is unique in its geopolitical and commercial importance in the international system. The industry's Paris exemption, as noted above, is perhaps the clearest indication of its exceptional status. The source of Maersk's power is not just market dominance, but specifically market dominance in an industry that is essential to the majority of global commerce. The ongoing trend toward greater industry consolidation, particularly over the past decade, has only heightened the influence of major players. Put simply, major players such as Maersk are leveraging the industry's status as well as their market dominance to dictate the direction and scope of environmental governance, significantly enhancing their competitiveness along the way.

\section{$7 \quad$ Conclusion: The Path to Sustainability?}

The elephant in the room is whether, on balance, industry-driven governance is an effective mechanism for improving the overall environmental performance of the container shipping industry. It certainly is leading to short-term incremental improvements, but the answer is murkier with respect to strategic longrun advances. The progressive stance of companies such as Maersk on reducing greenhouse gas emissions is an important normative shift within the industry. It is certainly desirable that some of the largest companies in the world's oldest transnational industry are acknowledging their environmental impacts. Such efforts are certainly better than avoidance and obfuscation, as has been common in the past. In addition, many of the technological advances in shipping are helping to decrease environmental consequences. The shipping industry is 
not going anywhere, so these advances are necessary if it is to become more sustainable.

Yet we need to keep in mind that corporate self-governance of environmental matters is further consolidating power and authority within the shipping industry. Concentration is happening on two fronts. First, industry selfgovernance is co-opting governance from state-led processes. Industry increasingly decides which problems to address and how to address them. These decisions tend to lead to marginal, incremental steps that benefit business by minimizing any impact on profitability. Fuel efficiency gains, for example, do not compensate for rapid growth in global shipping. On aggregate, the environmental impact of the industry is rising despite better efficiency. As noted, international shipping currently accounts for 3 percent of global greenhouse gas emissions. One European Union study predicts that this percentage will rise to 17 percent by 2050, if left unregulated. ${ }^{45}$ Private governance alone is not enough to reduce this impact meaningfully. The problem is compounded because shipping is a derived demand industry, so its impact also depends on unregulated global consumption levels and supply chains. ${ }^{46}$ The current industry-led approach nonetheless risks being a linear solution to an exponential problem.

Second, major industry players in container shipping are using environmental regulation as a tool to enhance their market dominance, leading to even greater consolidation of the industry. It is not necessarily problematic for industry leaders like Maersk to raise the bar of environmental performance and force laggards to follow suit. But as noted above, this could be problematic for global shipping because smaller companies cannot keep up in an already centralized industry with low profit margins, aggravating already existing inequities common across the international political economy. Sustainability has become, in part, a competitive tool for some corporate players to make the industry even less democratic. It can raise costs that are more easily absorbed by large companies, put a premium on economies of scale, and increase barriers to entry: all further enhancing the power and authority of major companies to dictate governance. Industry sustainability initiatives are, unexpectedly, hastening global shipping's march toward becoming a global oligopoly, if it is not already there.

We could arguably consider this trade-off between consolidation and a commitment to environmental self-governance a good thing for the industry's per-

45 Cames et al. 2015, 28.

46 Rodrigue, Comtois, and Slack 2017. 
formance. If it meant sustainability in global shipping, then perhaps the case could be made that a less democratic industry is an acceptable cost. The prevailing question is whether a few large container shipping companies, increasingly self-regulating, will be willing to make greater sacrifices for sustainability to prevent the bleaker projections of the industry's environmental impact from becoming reality.

\section{Bibliography}

Alexandrou, George, Dimitrios Gounopoulos, and Hardy M. Thomas. "Mergers and Acquisitions in Shipping." Transportation Research 61 (2014), 212-234.

A.P. Møller-Mærsk A/S. 2017 Sustainability Report (Copenhagen: A.P. Møller-Mærsk $\mathrm{A} / \mathrm{S}, 2018)$.

Bernstein, Steven. The Compromise of Liberal Environmentalism (New York: Columbia University Press, 2001).

Cames, Martin, Jakob Graichen, Anne Siemons, and Vanessa Cook. Emission Reduction Targets for International Aviation and Shipping (Brussels: European Union, 2015).

Capaldo, Kevin, James J. Corbett, Prasad Kasibhatla, Paul Fischbeck, and Spyros N. Pandis. "Effects of Ship Emissions on Sulphur Cycling and Radiative Climate Forcing over the Ocean." Nature 400 (6746) (1999), 743-746.

Clapp, Jennifer. "Mega-Mergers on the Menu: Corporate Concentration and the Politics of Sustainability in the Global Food System." Global Environmental Politics 18 (2) (2018), 12-33.

Cutler, A. Claire. "Private Authority in International Trade Relations: The Case of Maritime Transport." In Private Authority and International Affairs, eds. A. Claire Cutler, Virginia Haufler, and Tony Porter (Albany: SUNY Press, 1999), 283-331.

Dauvergne, Peter, and Jane Lister. Eco-Business: A Big-Brand Takeover of Sustainability (Cambridge: MIT Press, 2013).

DeSombre, Elizabeth. Flagging Standards: Globalization and Environmental, Safety, and Labor Regulations at Sea (Cambridge: MIT Press, 2006).

DeSombre, Elizabeth. "Globalization, Competition, and Convergence: Shipping and the Race to the Middle." Global Governance 14 (2) (2008), 179-198.

Endresen, Øyvind, Eirik Sørgård, Hanna Lee Behrens, Per Olaf Brett, and Ivar S.A. Isaksen. "A Historical Reconstruction of Ships: Fuel Consumption and Emissions." Journal of Geophysical Research: Atmospheres 112 (D12) (2007).

Eyring, Veronika, H.W. Köhler, J. Van Aardenne, and A. Lauer. "Emissions from International Shipping: 1. The Last 50 Years." Journal of Geophysical Research: Atmospheres 110 (D17) (2005).

Franck, Bernard, and Jean-Claude Bunel. “Contestability, Competition and Regulation: 
The Case of Liner Shipping." International Journal of Industrial Organization 9 (1) (1991), 141-159.

InfluenceMap. Corporate Capture of the IMO (London: InfluenceMap, 2017).

International Maritime Organization. Third IMO Greenhouse Gas Study 2014 (London: International Maritime Organization, 2015).

International Monetary Fund. Trade Interconnectedness: The World with Global Value Chains (Washington: International Monetary Fund, 2013).

International Tanker Owners Pollution Federation. Oil Tanker Spill Statistics 2018 (London: International Tanker Owners Pollution Federation, 2018).

International Transport Forum. Shipping Emissions in Ports (Paris: International Transport Forum, Organisation for Economic Co-operation and Development, 2014).

International Transport Forum. The Impact of Mega-Ships (Paris: International Transport Forum, Organisation for Economic Co-operation and Development, 2015).

International Transport Forum. The Impact of Alliances in Container Shipping (Paris: International Transport Forum, Organisation for Economic Co-operation and Development, 2018).

Johnson, Robert C., and Guillermo Noguera. Fragmentation and Trade in Value Added over Four Decades (Cambridge, MA: National Bureau of Economic Research, 2012).

Lister, Jane, René Taudal Poulsen, and Stefano Ponte. "Orchestrating Transnational Environmental Governance in Maritime Shipping." Global Environmental Change 34 (2015), 185-195.

Malhotra, Neil, Benoît Monin, and Michael Tomz. "Does Private Regulation Preempt Public Regulation?" American Political Science Review 113 (1) (2019), 19-37.

Mikler, John. The Political Power of Global Corporations (Cambridge: Polity, 2018).

Mitchell, Ronald. "Regime Design Matters: Intentional Oil Pollution and Treaty Compliance." International Organization 48 (3) (1994), 425-458.

Molloy, Ned. The IMO's 2020 Global Sulfur Cap: What a 2020 Sulfur-Constrained World Means for Shipping Lines, Refineries and Bunker Suppliers (London: Platts, 2016).

Munari, Francesco. “Competition in Liner Shipping." In The Hamburg Lectures on Maritime Affairs 2009 \& 2010, eds. Jürgen Basedow, Ulrich Magnus, and Rüdiger Wolfrum (New York: Springer, 2012), 3-27.

Nyman, Elizabeth. "Outpaced by Events: Our Ageing Law of the Sea." International Journal of Maritime History 29 (3) (2017), 636-644.

Pålsson, Henrik. Environmental Freight Transport Practices in Swedish Companies (Lund: Lund University, 2015).

Rodrigue, Jean-Paul, Claude Comtois, and Brian Slack. The Geography of Transport Systems, 4th ed. (New York: Routledge, 2017).

Stiglitz, Joseph E. People, Power, and Politics: Progressive Capitalism for an Age of Discontent (New York: Norton, 2019).

Strange, Susan. “Who Runs World Shipping?" International Affairs $5^{2}$ (3) (1976), 346367 . 
Sys, Christa. "Is the Container Liner Shipping Industry an Oligopoly?" Transport Policy 16 (5) (2009), 259-270.

Thomson Reuters. Thomson ONE. [n.d.]. https://thomsonone.com.

UN Conference on Trade and Development. Review of Maritime Transport 1976 (New York: UN Conference on Trade and Development, 1976).

UN Conference on Trade and Development. Self-Regulation of Environmental Management (New York: UN Conference on Trade and Development, 2003).

UN Conference on Trade and Development. Review of Maritime Transport 2017 (New York: UN Conference on Trade and Development, 2017).

UN Conference on Trade and Development. Review of Maritime Transport 2019 (New York: UN Conference on Trade and Development, 2019).

UN Conference on Trade and Development. Review of Maritime Transport 2020 (New York: UN Conference on Trade and Development, 2020).

Wan, Zheng, Mo Zhu, Shun Chen, and Daniel Sperling. "Pollution: Three Steps to a Green Shipping Industry." Nature 530 (759o) (2016), 275-277.

Wang, Jasmine, Kyunghee Park, and Natasha Khan. "Maersk Wants Hong Kong to Ban Dirty Fuel to Fight Smog." Bloomberg, 6 January 2013.

Wilks, Stephen. The Political Power of the Business Corporation (Northampton: Edward Elgar, 2013).

World Integrated Trade Solution. "World Intermediate Goods Exports by Country and Region 2016." Available at: https://wits.worldbank.org/Default.aspx?lang=en. Accessed 18 February 2018.

World Shipping Council. "Container Ship Design.” Available at: https://www.worldship ping.org/about-the-industry/liner-ships/container-ship-design. Accessed 7 January 2021. 